\title{
The Role of Cytokines TGF- $\beta 1$ and FGF-1 in the Expression of Characteristic Markers of Rat Liver Myofibroblasts Cultured in Three-Dimensional Collagen Gel
}

\author{
E. PETEROVÁ ${ }^{1}$, A. MRKVICOVÁ ${ }^{1}$, L. PODMOLÍKOVÁ ${ }^{1}$, M. ŘEZÁČOVÁ ${ }^{1}$, J. KANTA $^{1}$ \\ ${ }^{1}$ Department of Medical Biochemistry, Faculty of Medicine in Hradec Králové, Charles University \\ in Prague, Hradec Králové, Czech Republic
}

Received June 5, 2015

Accepted March 18, 2016

On-line July 15, 2016

\section{Summary}

Rat liver myofibroblasts (MFB) are the key cells involved in the deposition of extracellular matrix in fibrotic liver. They were isolated by repeated passaging of non-parenchymal cell fraction and cultured in 3-dimensional (3D) collagen gel mimicking tissue. The transfer of MFB from plastic dishes to collagen resulted in the change in their shape from large and spread to slender with long extensions. The expression of transforming growth factor- $\beta 1$ (TGF- $\beta 1$ ) and of MFB markers, a-smooth muscle actin (a-SMA) and cellular fibronectin (EDA-FN), on protein level was significantly decreased in collagen gel. The gel did not change the expression of metalloproteinase MMP-2 but activated the proenzyme. The experiments with inhibitors of metabolic pathways showed that EDA-FN and a-SMA were differently regulated. The expression of EDA-FN required functional TGF- $\beta 1$ receptors and was also dependent on the activity of protein kinases MEK1 and MEK2. a-SMA expression was primarily determined by the $3 \mathrm{D}$ environment. Fibroblast growth factor- 1 (FGF-1) in combination with heparin decreased the expression of a-SMA and increased the expression of EDA-FN in the cells on plastic. The cellular environment may influence the cells per se and may modify the action of other agents.

\section{Key words}

Liver myofibroblasts - a-smooth muscle actin - Cellular fibronectin - Matrix metalloproteinase-2 - TGF- $\beta 1$ - FGF-1 • Protein kinases

\section{Corresponding author}

J. Kanta, Faculty of Medicine in Hradec Králové, Šimkova 870, 50038 Hradec Králové, Czech Republic. Fax: +420 495512715. E-mail: kanta@Ifhk.cuni.cz

\section{Introduction}

Myofibroblasts (MFB) are the main cellular type responsible for tissue repair. They are involved in wound contraction, remodeling of provisional wound matrix and forming of the scar. They are contractile cells due to the presence of $\alpha$-smooth muscle actin ( $\alpha$-SMA) containing stress fibers. They synthesize extracellular matrix (ECM) components and produce enzymes involved in tissue degradation and remodeling (Desmouliere et al. 2005). Various fibroblastic cells may acquire myofibroblastic phenotype. The main source of MFB in the liver are hepatic stellate cells (HSC) and portal fibroblasts. MFB are not present in normal liver but they appear in liver fibrosis (Iwaisako et al. 2012). They can be isolated from the nonparenchymal liver cell fraction released from the tissue by enzymatic treatment (Knittel et al. 1999, Ogawa et al. 2007, Jiroutová et al. 2013). MFB differentiation observed in vivo can be reproduced by culturing nonparenchymal liver cells on plastic dishes (Friedman et al. 1989, Guyot et al. 2006).

Cells in a tissue are surrounded with extracellular matrix (ECM), which is a network containing proteins, glycoproteins, proteoglycans and glycosaminoglycans. ECM provides both chemical and mechanical signals to cells. Chemical signals may originate in the chemical structure of ECM components or may be provided by cytokines and growth factors stored in the ECM and released from it under certain circumstances (Kanta 2015). The cells cultured in threedimensional (3D) environment acquire tissue-like 
phenotype and behave differently than the cells in conventional tissue culture on stiff plastic dishes, as far as their morphology, differentiation, migration, and proliferation is concerned (Plant et al. 2009). The most abundant ECM component in fibrotic tissue is type I collagen (Aumailley and Gayrand 1998, Ramadori et al. 1998). 3D collagen matrices are often used as a model to study cell behavior in the tissue-like environment (Grinnell and Petroll 2010).

Transforming growth factor- $\beta 1$ (TGF- $\beta 1)$ is a cytokine thought to have a key role in liver fibrogenesis (Gressner et al. 2002). It is produced by endothelial cells, lymphocytes, macrophages and platelets (Branton and Kopp 1999). Autoinduction of TGF- $\beta 1$ may occur in fibroblasts (Kelley et al. 1993, Wells et al. 2004). Nonparenchymal liver cells express this cytokines in $\mathrm{CCl}_{4}$-damaged liver (Date et al. 1998). TGF- $\beta 1$ forms a complex with receptors I and II and type I receptor phosphorylates signal transducers Smad2 and Smad3. The Smads enter the cell nucleus and regulate the transcription of specific genes (Inagaki and Okazaki 2007). Smad activity may be further modified by MAP kinases (ERK 1/2) that phosphorylate Smad3 (Leask and Abraham 2004).

TGF- $\beta 1$ induces the expression of $\alpha$-SMA, a marker of MFB differentiation, in fibroblastic cells of various origin (Malmström et al. 2004, Meyer-ter-Vehn et al. 2006, Hinz 2007). However, the induction is regulated by substrate stiffness; cell activation increases as the support becomes stiffer (Arora et al. 1999, Li et al. 2007).

TGF- $\beta 1$ stimulates cellular fibronectin synthesis and its incorporation into ECM (Ignotz and Massagué 1986, Ramadori et al. 1992). EDA type of cellular fibronectin (FN) is involved in fibroblast differentiation and is essential for fibrosis development (Muro et al. 2008, Kohan et al. 2010). EDA-FN deposition precedes $\alpha$-SMA expression during granulation tissue evolution in vivo (Serini et al. 1998).

Matrix metalloproteinase-2 (MMP-2) is expressed during liver fibrogenesis by $\alpha$-SMA containing cells. It is secreted as a proenzyme and activated by a membrane-type MMP (Préaux et al. 1999). The influence of TGF- $\beta 1$ on MMP-2 expression and activity varies from tissue to tissue. It is greatly enhanced in human ligament fibroblasts (Wang et al. 2011), weekly increased in rat tendon fibroblasts (Cui et al. 2011) and suppressed in rat lung fibroblasts (Ye et al. 2011).

Fibroblast growth factor-1 (FGF-1), also called acidic FGF (aFGF), is a member of the family of fibroblast growth factors. These cytokines control cell proliferation, migration and differentiation in various organs through different signal pathways (Boilly et al. 2000). FGF form a ternary receptor complex with tyrosine kinase and heparan sulfate glycosaminoglycan (McKeehan and Kan 1994). Heparin modulates FGF activity in this way (Turnbull and Gallagher 1993).

FGF-1 suppresses $\alpha 1(\mathrm{I})$ collagen expression and induces MMP-1 in cultured fibroblasts (Becerril et al. 1999) and decreases $\alpha$-SMA expression (Maltseva et al. 2001). It antagonizes the effect of TGF- $\beta 1$ on $\alpha$-SMA expression in fibroblasts (Ramos et al. 2006). FGF-1 actions can be characterized as the induction of the antifibrogenic phenotype. On the other hand, liver fibrosis is decreased in mice deficient in FGF-1 and -2 and chronically exposed to carbon tetrachloride treatment (Yu et al. 2003). However, the effects of FGF-1 on liver myofibroblasts have not yet been studied.

The aim of this study was to compare the expression of MFB markers, $\alpha$-SMA, cellular fibronectin and MMP-2, in rat liver MFB embedded in 3D collagen gel with the expression in the cells cultured on standard plastic dishes. The role of TGF- $\beta 1$ pathway was studied using SB431542, the inhibitor of TGF- $\beta$ type I receptor. The inhibitor U0126 was used to study the role of MAP kinases. The effect of FGF-1 and heparin was tested in the cells cultured both in type I collagen gel and on plastic. TGF- $\beta 1$ and other cytokines are candidates for the treatment of cirrhosis and their testing should therefore include conditions resembling 3D structure of tissues.

\section{Methods}

\section{Animals}

Male Sprague-Dawley rats (Anlab, Prague, Czech Republic) were fed commercial pelleted diet ad libitum and were maintained in an air-conditioned room at $22{ }^{\circ} \mathrm{C}$. They were used at the age of 5 months when they weighed 450-550 g. The experiments were approved by the Committee for Work with Small Laboratory Animals of the Faculty of Medicine in Hradec Králové and by the Ministry of Education, Youth and Sports, File No. 40904/2011-30.

\section{Cell isolation and culture}

The rats were anesthetized with a mixture of ketamine (Narkamon, Bioveta, Ivanovice, Czech 
Republic) and xylazine (Xylased, Bioveta). The liver was perfused in situ through the portal vein with $\mathrm{Ca}^{2+}$-free Hanks balanced salt solution (HBSS; Gibco Life Technologies, Prague) for $10 \mathrm{~min}$, followed by $100 \mathrm{ml}$ of $0.2 \%$ pronase $\mathrm{E}(\mathrm{w} / \mathrm{v})$ (Roche, Prague) solution and by $200 \mathrm{ml}$ of $0.01 \%$ collagenase B (Serva, Heidelberg, Germany). The enzymes were dissolved in complete HBSS. Perfusion solutions were warmed in a water bath to maintain the temperature of the liver at $37^{\circ} \mathrm{C}$. The cell suspension was incubated in $0.001 \%$ DNase (Roche) for $30 \mathrm{~min}$. HSC fraction of liver cells was isolated by centrifugation on Optiprep (Axis-Shield, Oslo, Norway) gradient (Jiroutova et al. 2007). The cells were cultured in Dulbecco's modified Eagle medium (DMEM; Sigma, Prague) containing $10 \%$ fetal bovine serum (FBS; PAA, Cölbe, Germany), $4 \mathrm{mM}$ L-glutamine, $100 \mathrm{U} / \mathrm{ml}$ penicillin, and $100 \mu \mathrm{g} / \mathrm{ml}$ streptomycin (Sigma). MFB were obtained after 4 passages of the culture. They were cultured for $24 \mathrm{~h}$ before the tested agents were added.

FGF-1 was obtained from Peprotech (Rocky Hill, USA), heparin from porcine intestinal mucosa was obtained from Sigma. SB431542 (Sigma) was dissolved in dimethylsulfoxide (DMSO; Sigma) and used at final concentration of $100 \mathrm{nmol} / \mathrm{ml}$. The stock solution of U0126 (Cell Signaling, Danvers, USA) was in DMSO, final concentration was $30 \mathrm{nmol} / \mathrm{ml}$.

\section{Collagen gels}

A modified procedure of Elsdale and Bard (1972) was used to prepare collagen. Rat tail tendons were cut to small pieces, extracted with $0.15 \mathrm{M} \mathrm{NaCl}$ overnight and then with $0.25 \mathrm{M}$ acetic acid for $48 \mathrm{~h}$ with continuous stirring. The suspension was dialyzed against three exchanges of $0.02 \mathrm{M}$ acetic acid and centrifuged at $16,000 \mathrm{~g}$ for $40 \mathrm{~min}$. All these manipulations were done at $4{ }^{\circ} \mathrm{C}$. Collagen concentration was adjusted to $1.33 \mathrm{mg} / \mathrm{ml}$. Filter-sterilized collagen solution was mixed with $4 \times$ DMEM in the ratio $3: 1(\mathrm{v} / \mathrm{v})$. The $\mathrm{pH}$ of the mixture was neutral judging by the color of the indicator present in DMEM. The cells (230 thousands in $40 \mu \mathrm{l}$ of DMEM) were introduced into $2 \mathrm{ml}$ of the mixture in Petri $35 \mathrm{~mm}$ dishes. The gels were allowed to polymerize in the $\mathrm{CO}_{2}$ incubator for $1 \mathrm{~h}$ at $37^{\circ} \mathrm{C}$ and then they were overlayed with the same volume of DMEM containing $20 \%$ FBS and antibiotics. The resulting concentration of FBS was $10 \%$. The same numbers of cells were plated on plastic dishes without collagen.
$R N A$ isolation and quantitative reverse transcription polymerase chain reaction ( $q R T-P C R$ )

The cells on plastic were scraped in phosphate buffered saline (PBS), centrifuged and dissolved in guanidine thiocyanate (GTC) containing mercaptoethanol (Jiroutova et al. 2007). The gels were centrifuged at $12,000 \mathrm{~g}$ for $4 \mathrm{~min}$ and dissolved in saturated GTC containing mercaptoethanol. Total cellular RNA was extracted according to Chomczynski and Sacchi (1987) and purified using RNeasy Mini Kit (Qiagen, Hilde, Germany). RNA was reverse transcribed using cDNA Reverse Transcription Kit (Applied Biosystems Life Technologies, Prague) and quantified with TaqMan Gene Expression Assays (Applied Biosystems). The results were normalized to $18 \mathrm{~S}$ RNA expression.

\section{Western blot analysis}

The cells were scraped from the plastic, suspended in PBS containing $4 \mathrm{mM}$ EDTA and washed 3 fold with this solution. Collagen gel was dissolved by Clostridium histolyticum collagenase NB $4 \mathrm{G}$ proved grade (Serva, Heidelberg, Germany). The cells were washed 3 fold with EDTA-containing PBS. The proteins were extracted with cell lysis buffer (Cell Signaling). Protein content was determined with bicinchoninic acid (Sigma). Ten $\mu \mathrm{g}$ protein were applied on Novex NuPAGE 4-12\% Bis-Tris gel (Invitrogen Life Technologies, Prague) under nonreducing conditions. The proteins were transferred to $0.2 \mu \mathrm{m}$ Hybond nitrocellulose membrane (GE Healthcare, München, Germany). Staining with Ponceau $\mathrm{S}$ was used as a loading control. The membranes were incubated with antibodies to $\alpha$-SMA (1A4, Sigma), cellular fibronectin (IST-9; Santa Cruz Biotechnology, Heildelberg, Germany) or MMP-2 (H-76, Santa Cruz), TGF- $\beta 1$ (V, Santa Cruz), Smad2/3 (D7G7, Cell Signaling), Phospho-Smad2 (Ser465/467)/Smad3 (Ser423/425) (D27F4, Cell Signaling) at $4{ }^{\circ} \mathrm{C}$ overnight. The secondary antibodies were from Santa Cruz. Detection was done with Western Blotting Luminol Reagent (Santa Cruz). The blots were scanned, quantified by program QUANTITY ONE 4.6 and normalized to the respective controls.

\section{Immunocytochemistry}

The cells were cultured for $24 \mathrm{~h}$. FGF-1, heparin or SB431542 were then added and the cells were harvested $48 \mathrm{~h}$ later. Cells on collagen gel were fixed by paraformaldehyde and permeabilized with $0.1 \%$ Triton 
$\mathrm{X}-100$. The unspecific binding was blocked with $1 \%$ FBS for $30 \mathrm{~min}$. The cells were incubated with the antibody to $\alpha$-SMA (1A4, Sigma) at $4{ }^{\circ} \mathrm{C}$ overnight. Polyclonal Goat Anti-Mouse Immunoglobulins/HRP (Dako) as a secondary antibody was applied in dark for $1 \mathrm{~h}$. The nuclei were stained with DAPI. The slides were mounted in Vectashield mounting medium for fluorescence H-1000 (Vector, Peterborough, United Kingdom) and examined by fluorescence microscopy.

\section{Zymography}

The activity of MMPs was measured in culture media. The cells were cultured on collagen gels for $24 \mathrm{~h}$, released by trypsin treatment and plated on plastic for $24 \mathrm{~h}$. The cells cultured on plastic were trypsinized and replated. Culture medium was harvested and protein concentration was adjusted to $1 \mathrm{mg} / \mathrm{ml}$. Ten microliter samples were electrophoresed in $8 \%$ SDS-polyacryl- amide gel containing $0.1 \%$ gelatin. The gel was washed with $2.5 \%$ Triton $\mathrm{X}-100$ twice for $30 \mathrm{~min}$ and subsequently incubated for $16 \mathrm{~h}$ at $37^{\circ} \mathrm{C}$ in $50 \mathrm{mmol} / \mathrm{l}$ Tris- $\mathrm{HCl}$ buffer $\mathrm{pH} 7.4$ containing $15 \mathrm{mmol} / \mathrm{l}$ sodium chloride and $10 \mathrm{mmol} / \mathrm{l}$ calcium chloride. The gel was stained with Coomassie brilliant blue and destained.

\section{ELISA determination}

Levels of extracellular TGF- $\beta 1$ was determined in culture media using commercial ELISA kits for TGF- $\beta 1$ (Invitrogen Life Technologies, Prague) according to the manufacturer's instructions. The cells were cultured on plastic or on gel for $24 \mathrm{~h}$ before the tested agents (FGF-1, heparin, SB431542 or U0126) were added. The cultivation intervals used are given in Figures and Tables. The minimum detectable dose of TGF- $\beta 1$ is less than $15.6 \mathrm{pg} / \mathrm{ml}$. The total amount of TGF- $\beta 1$ was normalized to the number of cells and media volume.

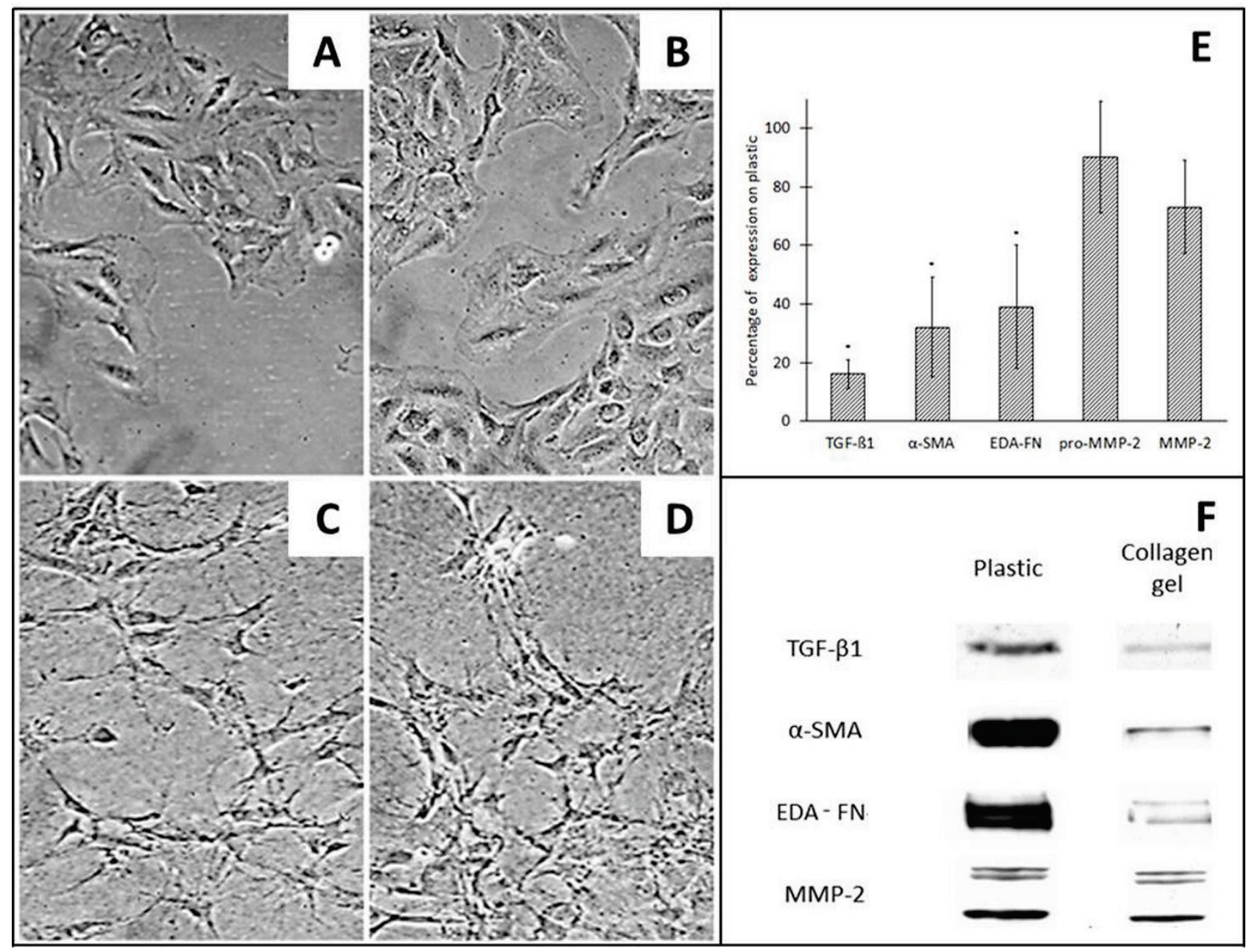

Fig. 1. Morphology of MFB. The cells were cultured for $72 \mathrm{~h}$ on plastic (A, B) or in collagen gel (C, D). FGF-1 plus heparin was added after the first $24 \mathrm{~h}$ (B, D). Magnification 100x. Protein expression in MFB cultured for $72 \mathrm{~h}$ on plastic or in collagen gel. Protein extracts of the cells were subjected to Western analysis. The blots were scanned. The results are shown as percentage of the expression on plastic (E). Means \pm S.E.M. $(n=5)$, * statistically significant results $(p \leq 0.05)$. Examples of Western blots $(1$ of 5 independent determinations) (F) 


\section{Statistical analysis}

Two-tailed Student's t-test was used to evaluate the statistical significance of the results. The significance level was $p=0.05 . \mathrm{n}$ in the legends indicates the number of independent experiments (MFB from different animals).

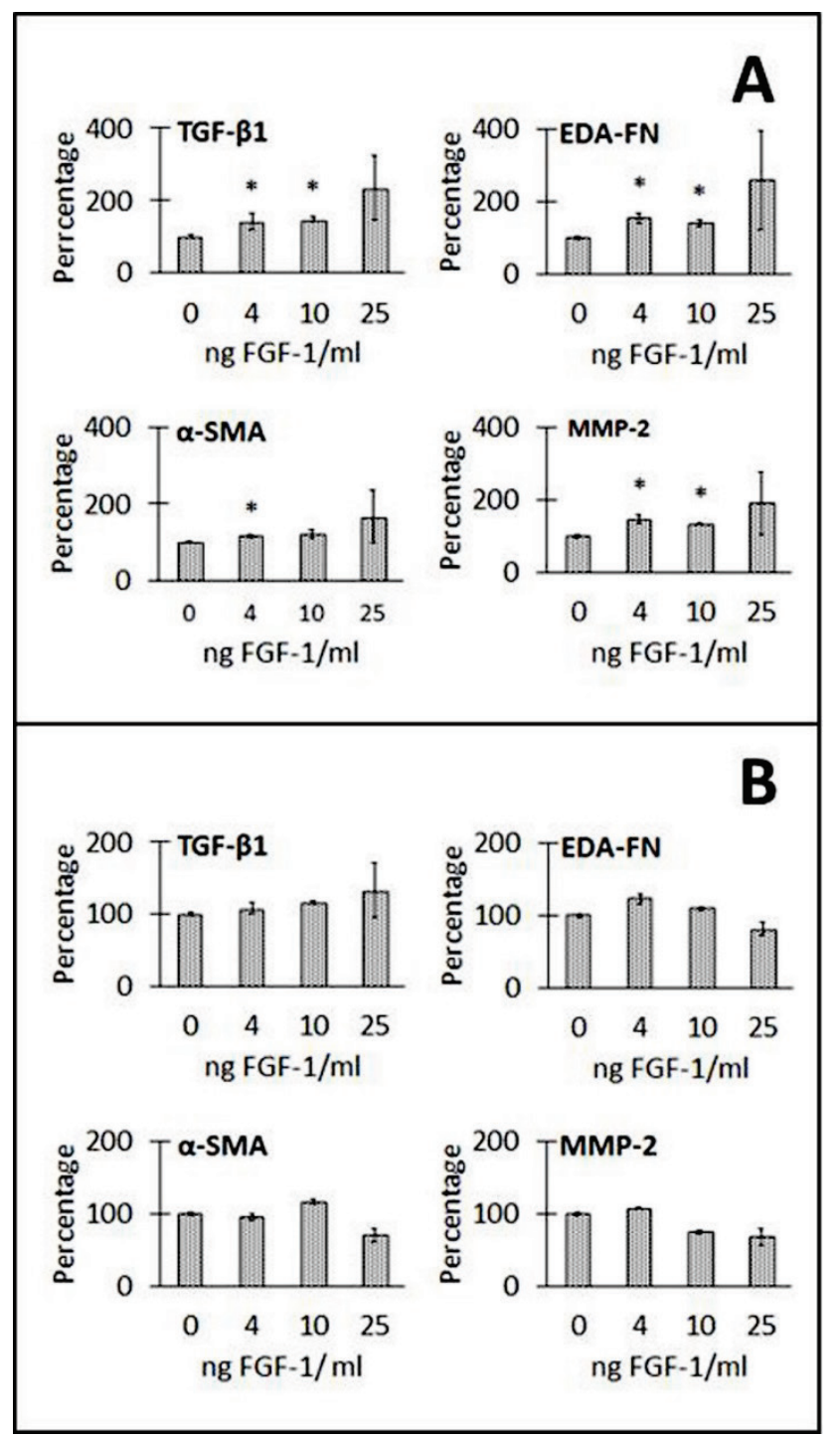

Fig. 2. mRNA expression in MFB cultured on plastic (A) or in collagen gel (B). FBS concentration was $0.5 \%$, heparin was not present. FGF-1 was added at the indicated concentrations $24 \mathrm{~h}$ after plating the cells and the cells were harvested after consecutive $16 \mathrm{~h}$. The results are expressed as percentage of the untreated control. Means \pm S.E.M. $\quad(n=3), *$ statistically significant results $(p \leq 0.05)$

\section{Results}

The 4fold passaged MFB spread on plastic surface (Fig. 1A). However, when they were embedded in collagen gel, they assumed a slender shape with long extensions and aggregated (Fig. 1C). The addition of
FGF-1 and heparin did not have any effect on cell morphology (Fig. 1B, D). The expression of the proteins characteristic of MFB was evaluated by Western analysis. When the cells were harvested $72 \mathrm{~h}$ after transfer to collagen gel, the level of TGF- $\beta 1$ was reduced to $16 \%$ in the $3 \mathrm{D}$ environment when compared to parallel cultures on plastic. The level of $\alpha$-SMA decreased to $32 \%$ and the level of EDA-FN to $39 \%$. The expression of MMP-2 did not change significantly (Fig. 1E, F).

The concentration of FGF-1 used in experiments with cells in vitro varies from 1 to $80 \mathrm{ng} / \mathrm{ml}$. Heparin that increases the effect of FGF-1 is often used in concentrations of 5 to $100 \mu \mathrm{g} / \mathrm{ml}$ (Maltseva et al. 2001, Becerril et al. 1999). We tested the effects of FGF-1 alone in concentrations ranging from $4 \mathrm{ng}$ to $25 \mathrm{ng} / \mathrm{ml}$ of culture medium containing $0.5 \%$ FBS without heparin. MFB were plated on plastic dishes (Fig. 2A) or embedded in collagen gel (Fig. 2B). Changes in the mRNA expression of four genes characteristic of MFB, TGF- $\beta 1$, EDA-FN, $\alpha-S M A$ and MMP-2, were found at the lowest tested concentration, especially in the cells cultured on plastic. Untreated cells were used as control. The highest tested concentration produced results that differed most from the control but the results varied greatly and were not statistically significant.

The concentration of $4 \mathrm{ng}$ FGF-1/ml was used in further experiments. To increase the effect of FGF-1, heparin was added at concentration $10 \mu \mathrm{g} / \mathrm{ml}$. Culture medium contained $10 \%$ FBS. The influence of FGF-1 and heparin on the cells on plastic or in collagen during $96 \mathrm{~h}$ experiments is shown in Figure 3. The drugs were added to the cultures $24 \mathrm{~h}$ after plating. Each result was normalized to the untreated control harvested at the respective time interval and the asterisks indicate statistical significance of the results compared to this control. To show the difference in the protein expression between plastic and collagen gel, the level of the expression on plastic was considered $100 \%$. FGF-1 plus heparin increased the expression of EDA-FN protein in the first $72 \mathrm{~h}$ in the cells on plastic but decreased the expression of $\alpha$-SMA. The expression of EDA-FN and $\alpha$-SMA in the cells embedded in collagen was insignificantly decreased at certain time intervals. TGF- $\beta 1$ protein was not detectable by Western blotting at some time intervals (not shown) and therefore ELISA determination of the extracellular TGF- $\beta 1$ concentration was used. The concentration of TGF- $\beta 1$ secreted into the medium by the cells in collagen gel was significantly lower than that secreted by the cells on plastic. TGF- $\beta 1$ 
levels were not much affected by the combination of FGF-1 and heparin (Fig. 3, Table 1). MMP-2 protein expression was not influenced by FGF-1 with heparin
(Fig. 3). However, the activity of MMP-2 in the cells cultured on plastic was inhibited by drug combination (Fig. 4J).

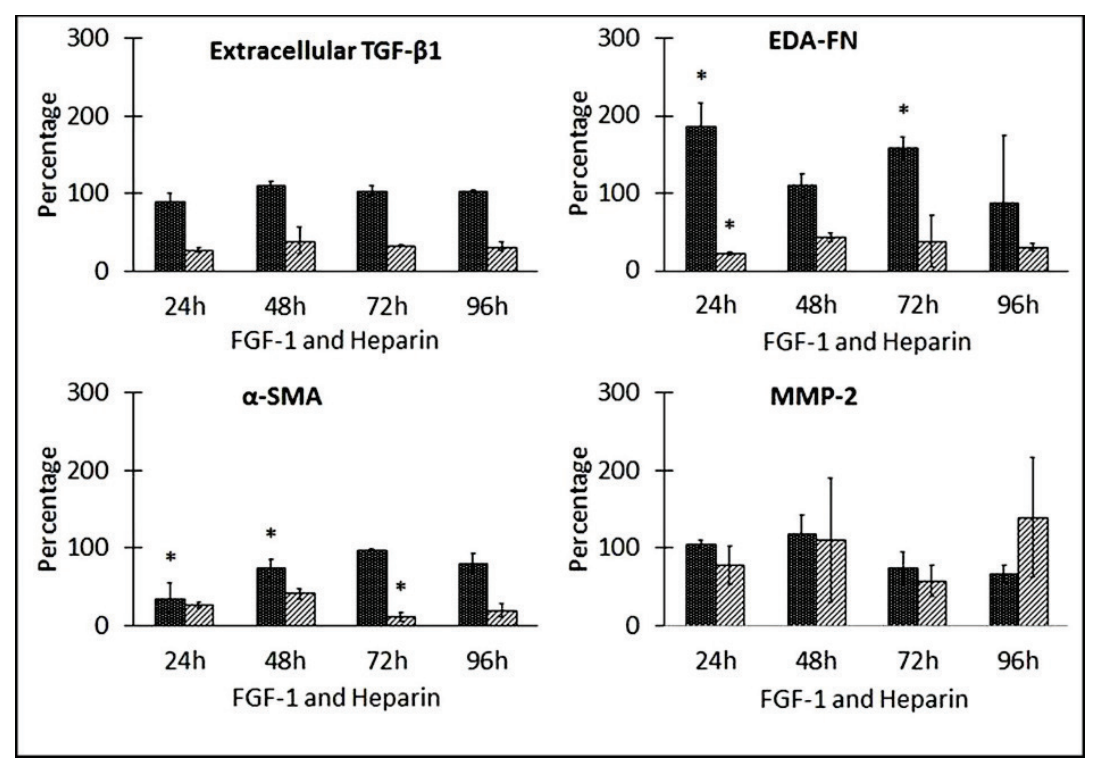

Fig. 3. Protein expression in MFB cultured on plastic (dark columns) or in collagen gel (light columns). FBS concentration was $10 \%$. FGF-1 plus heparin were added $24 \mathrm{~h}$ after cell plating and the cells were harvested later at the indicated time intervals. The asterisks indicate statistical significance of the results compared to the untreated control at the respective time interval. To show the difference in the protein expression between plastic and collagen gel, the level of the expression on plastic was considered $100 \%$. Means \pm S.E.M. $(n=3), *$ statistically significant results $(\mathrm{p} \leq 0.05)$
Table 1. TGF- $\beta 1$ content $(\mathrm{pg} / \mathrm{ml})$ determined by ELISA in the medium of MFB cultured on plastic or in collagen gel.

\begin{tabular}{lccc}
\hline Time (h) & $\mathbf{2 4}$ & $\mathbf{4 8}$ & $\mathbf{4 8}$ \\
FGF-1 $(\mathbf{4} \mathbf{~ n g} / \mathbf{m l})$ & - & - & + \\
Heparin $(\mathbf{1 0} \boldsymbol{\mu} \mathbf{g} / \mathbf{m l})$ & - & - & + \\
\hline Plastic & $124 \pm 14$ & $133 \pm 11$ & $147 \pm 13$ \\
Collagen gel & $35 \pm 5^{*}$ & $43 \pm 7^{*}$ & $51 \pm 7^{*}$ \\
\hline
\end{tabular}

FBS concentration was $10 \%$. The samples were taken at the indicated time intervals after cell plating. The cells in collagen gel were compared to those on plastic. Means \pm S.E.M. $(n=3)$, * statistically significant results $(p \leq 0.05)$

SB 431542 inhibits the function of TGF- $\beta$ type I receptor (Inman et al. 2002). In our experiments, it inhibited phosphorylation of Smad3 and Smad2, both in the cells on plastic and in collagen (Fig. 4K, L) and prevented Smad2 phosphorylation induced by FGF-1 and heparin.

SB 431542 significantly decreased the expression of EDA-FN in the cells both on plastic and in collagen gel. $\alpha$-SMA expression was much less affected. MMP-2 was not significantly influenced (Fig. 5A, B). The effect of the inhibitor on the expression of $\alpha$-SMA in collagen-embedded cells is illustrated in Figure 4C, D. SB 431542 partially inhibited the secretion of TGF- $\beta 1$ into the culture medium both in cells on plastic and in collagen gel, in the presence or absence of FGF-1 and heparin (Fig. 5C).
U0126 is an inhibitor of mitogen-activated protein kinases MEK1 and MEK2 (Favata et al. 1998). It suppressed the expression of EDA-FN in the cells in collagen gel. Its effect on $\alpha$-SMA was not statistically significant. The cells cultured on plastic responded to the inhibitor by a slight decrease in $\alpha$-SMA and EDA-FN expression. MMP-2 expression was not significantly affected by U0126 either in 3D environment or on plastic (Fig. 5D, E). The secretion of TGF- $\beta 1$ into the medium was slightly inhibited (Fig. 5F).

\section{Discussion}

Rat MFB obtained by 4 passages of nonparenchymal fraction of liver cells spread well on plastic dishes. However, when they were embedded in collagen gel, they acquired a slender shape with long extensions. DNA synthesis and collagen expression are much higher in the cells cultured on stiff plastic than in the cells embedded in collagen gel attached to the walls of the culture dish (Lambert et al. 1992). Pathological stiffening of the tissue enhances fibrosis, while physiological levels of the tissue stiffness act as a brake on collagen synthesis. Exogenous TGF- $\beta 1$ or matrix stiffening can overcome this physiological brake (Liu et al. 2010). The changes in cell proliferation and synthetic activities are accompanied with changes in cell morphology (Kanta 2015). 


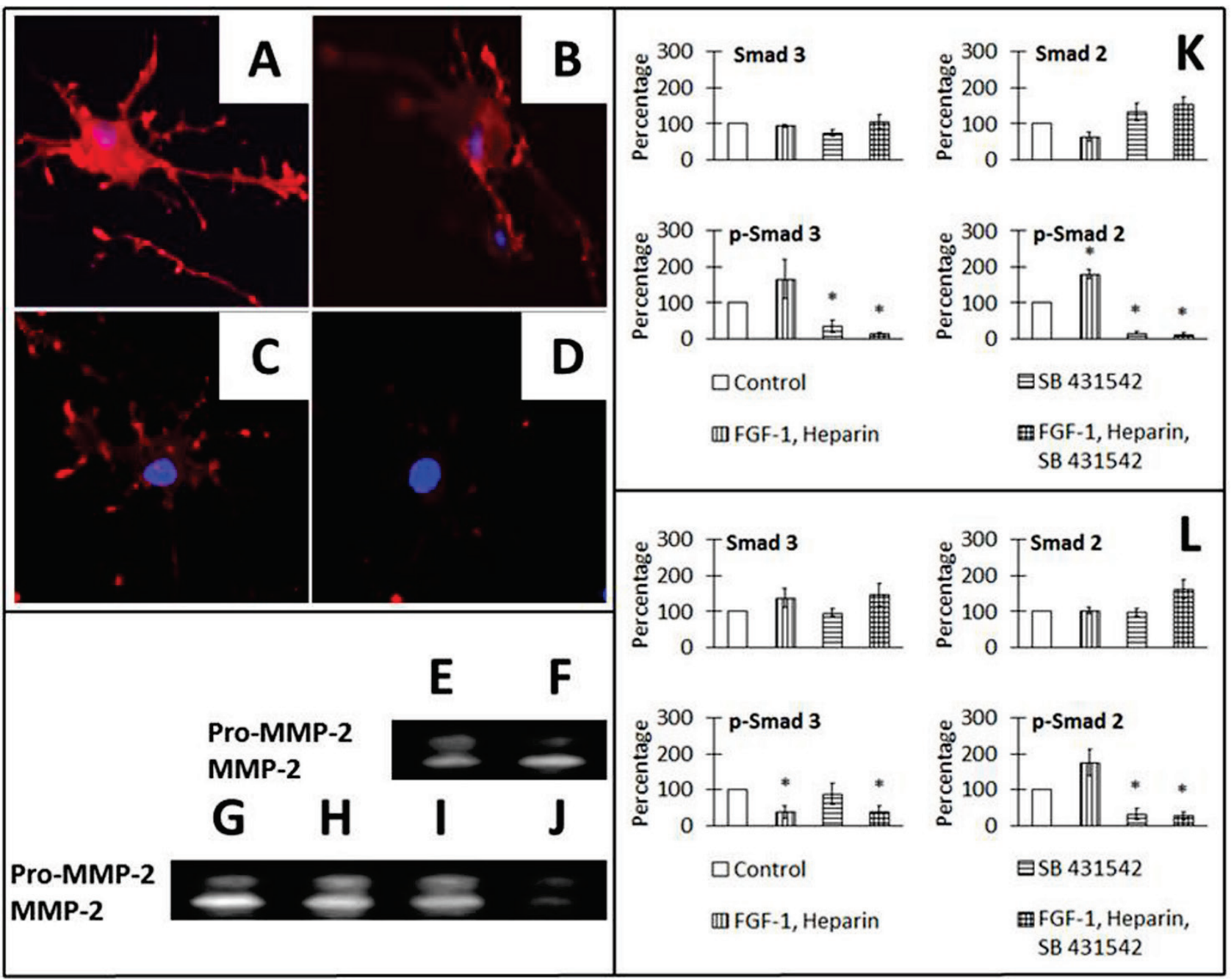

Fig. 4. Immunocytochemistry of MFB. The cells were cultured on collagen gel for $24 \mathrm{~h}$. FGF-1 plus heparin (B, C) or SB 431542 (C, D) were then added and the cells were cultured for another $48 \mathrm{~h}$. Control (A). MFB were stained with an antibody against a-SMA. FBS concentration was $10 \%$. Magnification 600x. Zymography of culture media. MFB were cultured on plastic (E, I, J) or on collagen gel (F, G, H). FGF-1 plus heparin were added to some cultures $(\mathbf{H}, \mathbf{J})$. The expression of Smad2 and Smad3 and their phosphorylated forms. MFB were cultured on plastic (K) or in collagen gel $(\mathbf{L})$ for $24 \mathrm{~h}$. The specified drugs were then added and the cells were harvested $48 \mathrm{~h}$ later. Means \pm S.E.M. $(n=3), *$ statistically significant results compared to untreated control $(p \leq 0.05)$

TGF- $\beta 1, \alpha-S M A$, EDA-FN and MMP-2 proteins were all expressed in our MFB. The concentration of immunoreactive TGF- $\beta 1$ in the culture medium of the cells embedded in collagen was significantly lower than that in the medium of cells cultured on plastic. The decrease in the key profibrotic cytokine TGF- $\beta 1$ expression in the cells growing in collagen after transfer from plastic is in agreement with the above theory. Mouse mammary epithelial cells transferred from plastic to EHS matrix give similar results (Streuli et al. 1993). The opposite was found with fibroblasts isolated from human skin biopsies (Varedi et al. 2000). The cause may reside in the tissue from which the cells were isolated and in the physiological state of the cells. The behavior of normal dermal cells resembles that of the fibroblasts cultured in collagen matrix detached from the walls of the dish and floating in the medium. These cells have very low proliferative capacity and ability to synthesize collagen (Grinnell 1994).

The inhibitor SB 431542 that blocks the activity of TGF- $\beta$ receptor type I (Inman et al. 2002) partially decreased the concentration of extracellular TGF- $\beta 1$ in the medium of MFB on plastic or in collagen gel. TGF- $\beta 1$ is known to autoregulate its own production (Kim et al. 1990) and this result may reflect this ability. TGF- $\beta 1$ secretion into the medium was also slightly decreased by U0126, the inhibitor of protein kinases MEK1 and MEK2.

The EDA-FN protein levels was significantly lower in the cells cultured in collagen gel than in the cells on plastic and it was further decreased by SB 431542 . This compound also inhibited phosphorylation of Smad3 
and Smad2. The low level of TGF- $\beta 1$ may be the cause of decreased expression of EDA-FN. EDA-FN expression by MFB in collagen gel was strongly dependent on the function of MEK1 and MEK2 kinases, especially in the cells in collagen gel.

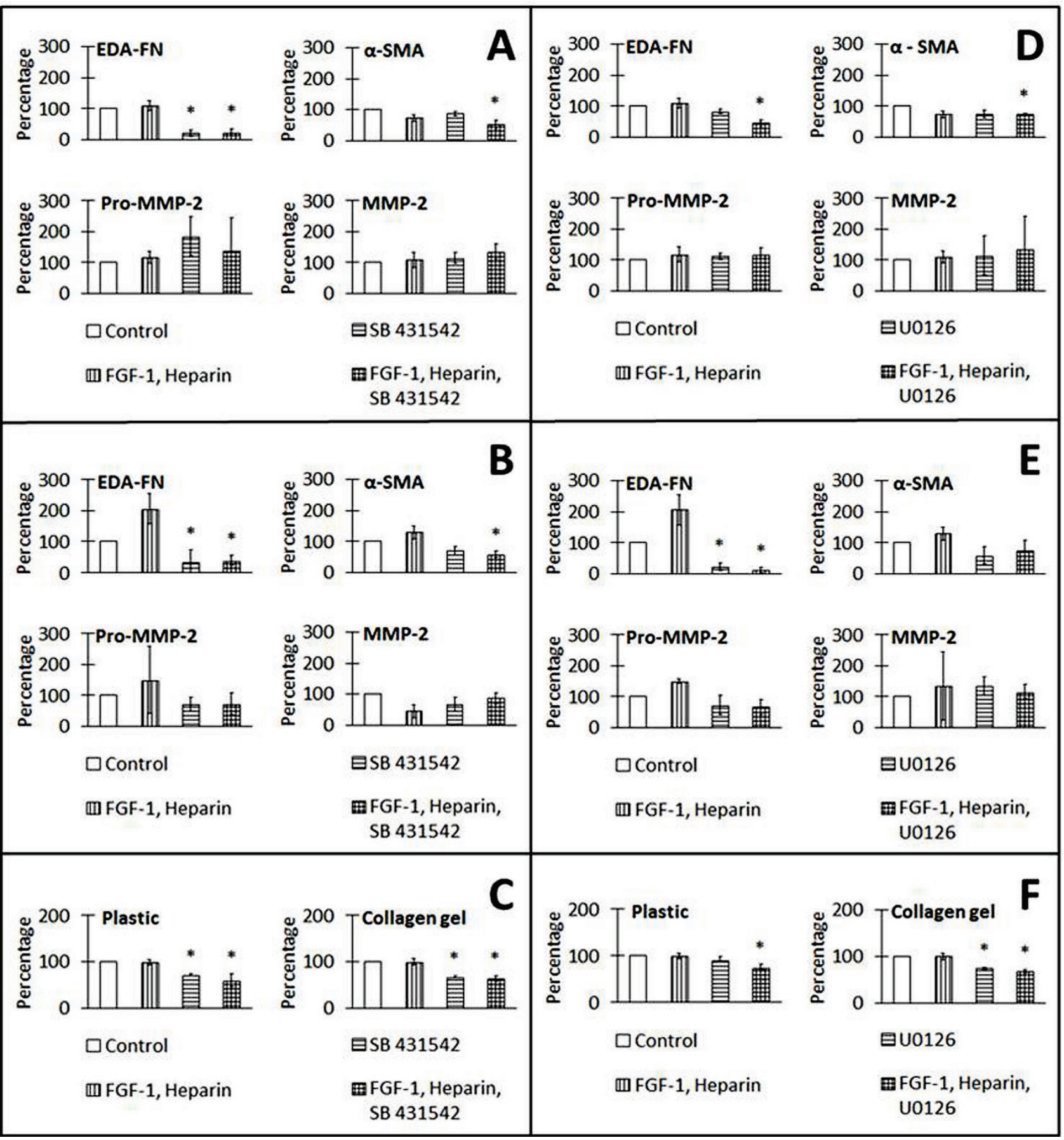

Fig. 5. Protein expression in MFB cultured on plastic $(\boldsymbol{A})$ or in collagen gel $(B)$ in the presence of the inhibitor SB 431542. All drugs were added $24 \mathrm{~h}$ after plating and the cells were harvested $48 \mathrm{~h}$ later. FBS concentration was $10 \%$. TGF- $\beta 1$ concentration in the medium was determined by ELISA (C). Protein expression in MFB cultured on plastic (D) or in collagen gel (E) in the presence of the inhibitor U0126. The drugs were added $24 \mathrm{~h}$ after plating the cells and the cells were harvested $48 \mathrm{~h}$ later. TGF- $\beta 1$ concentration in the medium was determined by ELISA (F). Means \pm S.E.M. $(n=3), *$ statistically significant results compared to untreated control $(p \leq 0.05)$

TGF- $\beta 1$ induces the formation of granulation tissue in vivo with abundant $\alpha$-SMA containing MFB (Desmouliere et al. 1993) and increases a-SMA expression in MFB embedded in collagen lattices in vitro. Fibronectin deposition precedes the expression of $\alpha$-SMA by fibroblasts in granulation tissue in vivo and 
after TGF- $\beta 1$ stimulation in vitro (Serini et al. 1998). The expressions of $\alpha$-SMA and fibronectin fibrils are induced by TGF- $\beta 1$ but while the $\alpha$-SMA appearance is reversible, that of fibronectin is not (Vaughan et al. 2000). The changes in EDA-FN level in our experiments did not parallel those in $\alpha$-SMA. The expression of $\alpha$-SMA was more influenced by the environment and differently dependent on signal pathways. The decrease in $\alpha$-SMA expression in collagen matrix was a dominant effect, while the blockade of TGF- $\beta 1$ receptor had a modifying influence. The expression of EDA-FN was much more sensitive to U0126, the inhibitor of MEK kinases (Favata et al. 1998), than the expression of $\alpha$-SMA.

MMP-2 expression in MFB was not significantly influenced by culturing the cells in $3 \mathrm{D}$ collagen gel. TGF$\beta 1$ is known to regulate metalloproteinase expression in many cells. It induces MMP-2 gene transcription and activity in cultured human ligament fibroblasts (Xie et al. 2013) but suppresses MMP-2 expression by rat dermal fibroblasts (Howard et al. 2012). The inhibitor of TGF- $\beta 1$ receptor function did not influence the expression of MMP-2 in our MFB. However, collagen gel induced activation of the proMMP-2, in agreement with the findings in human dermal fibroblasts (Seltzer et al. 1994) and in HSC (Théret et al. 1999).

FGF-1 with heparin induces antifibrogenic phenotype in human lung fibroblasts, decreases $\alpha$-SMA expression, reduces transcription of type I collagen and induces collagenase transcription (Becerril et al. 1999, Ramos et al. 2006). The combination of these drugs inhibits $\alpha$-SMA expression in rabbit corneal MFB (Maltseva et al. 2001). FGF-1 at the concentration of $20 \mathrm{ng} / \mathrm{ml}$ with $100 \mu \mathrm{g} / \mathrm{ml}$ heparin reverses the changes in morphology of human epithelial-like cells (Ramos et al. 2010). Cell morphology was not changed in our experiments where lower drug concentrations were used. MFB cultured on plastic responded to FGF-1 added with heparin by a decrease in $\alpha$-SMA protein and an increase in EDA-FN. The response of the cells in gel was weaker but in the same direction in the case of EDA-FN and $\alpha$-SMA. The activity of MMP-2 determined by zymography was inhibited by the drugs in the cells cultured on plastic. The expected antimyofibroblastic effect of FGF-1 was small in MFB cultured in the gel.

The culture of rat liver MFB in 3D collagen gel modified the expression of the key profibrotic cytokine TGF- $\beta 1$ and the expression of myofibroblastic markers EDA-FN and $\alpha$-SMA to a different extent. The expression of MMP-2 did not change but the proenzyme was activated. EDA-FN expression was dependent on TGF- $\beta 1$ and influenced by MAP kinases, while the expression of $\alpha$-SMA was primarily determined by the environment. The combination of FGF-1 with heparin had larger effects on MFB cultured on plastic than on those in collagen gel. When compared with the standard culture of MFB on plastic, individual variables were selectively influenced by the $3 \mathrm{D}$ collagen environment that simulates conditions in tissues. MFB markers were regulated differently by various signaling pathways.

\section{Conflict of Interest}

There is no conflict of interest.

\section{Acknowledgements}

This work was supported by the project PRVOUK P37/01.

\section{References}

ARORA PD, NARANI N, MCCULLOCH CAG: The compliance of collagen gels regulates transforming growth factor- $\beta$ induction of $\alpha$-smooth muscle actin in fibroblasts. Am J Pathol 154: 871-882, 1999.

AUMAILLEY M, GAYRAUD B: Structure and biological activity of the extracellular matrix. J Mol Med 76: 253-265, 1998.

BECERRIL C, PARDO A, MONTANO M, RAMOS C, RAMÍREZ R, SELMAN M: Acidic fibroblast growth factor induces an antifibrogenic phenotype in human lung fibroblasts. Am J Respir Cell Mol Biol 20: 1020-1027, 1999.

BOILLY B, VERCOUTTER-EDOUART AS, HONDERMARCK H, NURCOMBE V, LE BOURHIS X: FGF signals for cell proliferation and migration through different pathways. Cytokine Growth Factor Rev 11: 295-302, 2000 .

BRANTON MH, KOPP JB: TGF- $\beta$ and fibrosis. Microbes Infect 1: 1349-1365, 1999. 
CHOMCZYNSKI P, SACCHI N: Single-step method of RNA isolation by acid guanidinium thiocyanate-phenolchloroform extraction. Anal Biochem 162: 156-159, 1987.

CUI Q, WANG Z, JIANG D, QU L, GUO J, LI Z: HGF inhibits TGF- $\beta 1$-induced myofibroblast differentiation and ECM deposition via MMP-2 in Achilles tendon in rat. Eur J Appl Physiol 111: 1457-1463, 2011.

DATE M, MATSUZAKI K, MATSUSHITA M, SAKITANI K, SHIBANO K, OKAJIMA A, YAMAMOTO C, OGATA N, OKUMURA T, SEKI T, KUBOTA Y, KAN M, MCKEEHAN WL, INOUE K: Differential expression of transforming growth factor- $\beta$ and its receptors in hepatocytes and nonparenchymal cells of rat liver after $\mathrm{CCl}_{4}$ administration. J Hepatol 28: 572-581, 1998.

DESMOULIERE A, GEINOZ A, GABBIANI F, GABBIANI G: Transforming growth factor- $\beta 1$ induces $\alpha$-smooth muscle actin expression in granulation tissue myofibroblasts and in quiescent and growing cultured fibroblasts. J Cell Biol 122: 103-111, 1993.

DESMOULIERE A, CHAPONNIER C, GABBIANI G: Tissue repair, contraction, and the myofibroblast. Wound Rep Regen 13: 7-12, 2005.

ELSDALE T, BARD J: Collagen substrata for studies on cell behavior. J Cell Biol 54: 626-637, 1972.

FAVATA MF, HORIUCHI KY, MANOS EJ, DAULERIO AJ, STRADLEY DA, FEESER WS, VAN DYK DE, PITTS WJ, EARL RA, HOBBS F, COPELAND RA, MAGOLDA RL, SCHERLE PA, TRZASKOS JM: Identification of a novel inhibitor of mitogen-activated protein kinase kinase. J Biol Chem 273: 18623-18632, 1998.

FRIEDMAN SL, ROLL FJ, BOYLES J, ARENSON DM, BISSELL DM: Maintenance of differentiated phenotype of cultured rat hepatic lipocytes by basement membrane matrix. J Biol Chem 264: 10756-10762, 1989.

GRESSNER AM, WEISKIRCHEN R, BREITKOPF K, DOOLEY S: Roles of TGF-beta in hepatic fibrosis. Front Biosci 7: d793-d807, 2002.

GRINNELL F: Fibroblasts, myofibroblasts, and wound contraction. J Cell Biol 124: 401-404, 1994.

GRINNELL F, PETROLL WM: Cell motility and mechanics in three-dimensional collagen matrices. Annu Rev Cell Dev Biol 26: 335-361, 2010.

GUYOT C, LEPREUX S, COMBE C, DOUDNIKOFF E, BIOULAC-SAGE P, BALABAUD C, DESMOULIERE A: Hepatic fibrosis and cirrhosis: the (myo)fibroblastic cell subpopulations involved. Int J Biochem Cell Biol 38: $135-151,2006$.

HINZ B: Formation and function of the myofibroblast during tissue repair. J Invest Dermatol 127: 526-537, 2007.

HOWARD EW, CRIDER BJ, UPDIKE DL, BULLEN EC, PARKS EE, HAAKSMA CJ, SHERRY DM, TOMASEK JJ: MMP-2 expression by fibroblasts is suppressed by the myofibroblast phenotype. Exp Cell Res 318: 1542$1553,2012$.

IGNOTZ RA, MASSAGUÉ J: Transforming growth factor- $\beta$ stimulates the expression of fibronectin and collagen and their incorporation into the extracellular matrix. J Biol Chem 261: 4337-4345, 1986.

INAGAKI Y, OKAZAKI I: Emerging insights into transforming growth factor $\beta$ Smad signal in hepatic fibrogenesis. Gut 56: 284-292, 2007.

INMAN GJ, NICOLÁS FJ, CALLAHAN JF, HARLING JD, GASTER LM, REITH AD, LAPING NJ, HILL CS: SB-431542 is a potent and specific inhibitor of transforming growth factor- $\beta$ superfamily type I activin receptore-like kinase (ALK) receptors ALK4, ALK5, and ALK7. Mol Pharmacol 62: 65-74, 2002.

IWAISAKO K, BRENNER DA, KISSELEVA T: What's new in liver fibrosis? The origin of myofibroblasts in liver fibrosis. J Gastroent Hepatol 27 (Suppl 2): 65-68, 2012.

JIROUTOVA A, SLAVKOVSKY R, CERMAKOVA M., MAJDIAKOVA L., HANOVCOVA I, BOLEHOVSKA R, HAJZLEROVA M, RADILOVA H, RUSZOVA E, KANTA J: Expression of mRNAs related to connective tissue metabolism in rat hepatic stellate cells and myofibroblasts. Exp Toxicol Pathol 58: 263-273, 2007.

JIROUTOVÁ A, PETEROVÁ E, BITTNEROVÁ L, SLAVKOVSKÝ R, ČEVELOVÁ P, ŘEZÁČOVÁ M, CERMAN J, MIČUDA S, KANTA J: Collagenolytic potential of rat liver myofibroblasts. Physiol Res 62: 15-25, 2013.

KANTA J: Collagen matrix as a tool in studying fibroblastic cell behavior. Cell Adhes Migr 9: 308-316, 2015.

KELLEY J, SHULL S, WALSH JJ, CUTRONEO KR, ABSHER M: Auto-induction of transforming growth factor- $\beta$ in human lung fibroblasts. Am J Respir Cell Mol Biol 8: 417-424, 1993. 
KIM S-J, ANGEL P, LAFYATIS R, HATTORI K, KIM KY, SPORN MB, KARIN M, ROBERTS AB: Autoinduction of transforming growth factor $\beta 1$ is mediated by the AP-1 complex. Mol Cell Biol 10: 1492-1497, 1990.

KNITTEL T, KOBOLD D, PISCAGLIA F, SAILE B, NEUBAUER K, MEHDE M, TIMPL R, RAMADORI G: Localization of liver myofibroblasts and hepatic stellate cells in normal and diseased rat livers: distinct roles of (myo-)fibroblast subpopulations in hepatic tissue repair. Histochem Cell Biol 112: 387-401, 1999.

KOHAN M, MURO AF, WHITE ES, BERKMAN N: EDA-containing cellular fibronectin induces fibroblast differentiation through binding to $\alpha_{4} \beta_{7}$ integrin receptor and MAPK/Erk 1/2-dependent signaling. FASEB J 24: 4503-4512, 2010.

LAMBERT CA, SOUDANT EP, NUSGENS BV, LAPIERE CM: Pretranslational regulation of extracellular matrix macromolecules and collagenase expression in fibroblasts by mechanical forces. Lab Invest 66: 444-451, 1992.

LEASK A, ABRAHAM DJ: TGF- $\beta$ signaling and the fibrotic response. FASEB J 18: 816-827, 2004.

LI Z, DRANOFF JA, CHAN EP, UEMURA M, SÉVIGNY J, WELLS RG: Transforming growth factor- $\beta$ and substrate stiffness regulate portal fibroblast activation in culture. Hepatology 46: 1246-1256, 2007.

LIU F, MIH JD, SHEA BS, KHO AT, SHARIF AS, TAGER AM, TSCHUMPERLIN DJ: Feedback amplification of fibrosis through matrix stiffening and COX-2 suppression. J Cell Biol 190: 693-706, 2010.

MALMSTRÖM J, LINDBERG H, LINDBERG C, BRATT C, WIESLANDER E, DELANDER E-L, SÄRNSTRAND B, BURNS JS, MOSE-LARSEN P, FEY S, MARKO-VARGA G: Transforming growth factor- $\beta_{1}$ specifically induces proteins involved in the myofibroblast contractile apparatus. Mol Cell Proteomics 3: 466-477, 2004.

MALTSEVA O, FOLGER P, ZEKARIA D, PETRIDOU S, MASUR SK: Fibroblast growth factor reversal of the corneal myofibroblast phenotype. Invest Ophthalmol Vis Sci 42: 2490-2495, 2001.

MCKEEHAN WL, KAN M: Heparan sulfate fibroblast growth factor receptor complex: structure-function relationships. Mol Reprod Dev 39: 69-82, 1994.

MEYER-TER-VEHN T, GEBHARDT S, SEBALD W, BUTTMANN M, GREHN F, SCHLUNCK G, KNAUS P: p38 inhibitors prevent TGF- $\beta$-induced myofibroblast transdifferentiation in human tenon fibroblasts. Invest Ophthalmol Vis Sci 47: 1500-1509, 2006.

MURO AF, MORETTI FA, MOORE BB, YAN M, ATRASZ RG, WILKE CA, FLAHERTY KR, MARTINEZ FJ, TSUI JL, SHEPPARD M, BARALLE FE, TOEWS GB, WHITE ES: An essential role for fibronectin extra type III domain A in pulmonary fibrosis. Am J Respir Crit Care Med 177: 638-645, 2008.

OGAWA T, TATENO C, ASAHINA K, FUJII H, KAWADA N, OBARA M, YOSHIZATO K: Identification of vitamin A-free cells in a stellate cell-enriched fraction of normal rat liver as myofibroblasts. Histochem Cell Biol 127: 161-174, 2007.

PLANT AL, BHADRIRAJU K, SPURLIN TA, ELLIOTT JT: Cell response to matrix mechanics: focus on collagen. Biochim Biophys Acta 1793: 893-902, 2009.

PRÉAUX A-M, MALLAT A, NHIEU JTV, D’ORTHO M-P, HEMBRY RM, MAVIER P: Matrix metalloproteinase-2 activation in human hepatic fibrosis regulation by cell-matrix interactions. Hepatology 30: 944-950, 1999.

RAMADORI G, KNITTEL T, ODENTHAL M, SCHWÖLLER S, NEUBAUER K, MEYER ZUM BÜSCHENFELDE K-H: Synthesis of cellular fibronectin by rat liver fat-storing (Ito) cells: regulation by cytokines. Gastroenterology 103: 1313-1321, 1992.

RAMADORI G, KNITTEL T, SAILE B: Fibrosis and altered matrix synthesis. Digestion 59: 372-375, 1998.

RAMOS C, MONTANO M, BECERRIL C, CISNEROS-LIRA J, BARRERA L, RUÍZ V, PARDO A, SELMAN M: Acidic fibroblast growth factor decreases $\alpha$-smooth muscle actin expression and induces apoptosis in human normal lung fibroblasts. Am J Physiol Lung Cell Mol Physiol 291: L871-L879, 2006.

RAMOS C, BECERRIL C, MONTANO M, GARCÍA-DE-ALBA C, RAMÍREZ R, CHECA M, PARDO A, SELMAN M: FGF-1 reverts epithelial-mesenchymal transition induced by TGF- $\beta 1$ through MAPK/ERK kinase pathway. Am J Physiol Lung Cell Mol Physiol 299: L222-L231, 2010.

SELTZER JL, LEE A-Y, AKERS KT, SUDBECK B, SOUTHON EA, WAYNER EA, EISEN AZ: Activation of $72-\mathrm{kDa}$ type IV collagenase/gelatinase by normal fibroblasts in collagen lattices is mediated by integrin receptors but is not related to lattice contraction. Exp Cell Res 213: 365-374, 1994. 
SERINI G, BOCHATON-PIALLAT M-L, ROPRAZ P, GEINOZ A, BORSI L, ZARDI L, GABBIANI G: The fibronectin domain EDA-A is crucial for myofibroblastic phenotype induction by transforming growth factorß1. J Cell Biol 142: 873-881, 1998.

STREULI CH, SCHMIDHAUSER C, KOBRIN M, BISSELL MJ, DERYNCK R: Extracellular matrix regulates expression of the TGF- $\beta 1$ gene. J Cell Biol 120: 253-260, 1993.

THÉRET N, LEHTI K, MUSSO O, CLÉMENT B: MMP-2 activation by collagen I and concanavalin A in cultured human hepatic stellate cells. Hepatology 30: 462-468, 1999.

TURNBULL JE, GALLAGHER JT: Heparan sulphate: functional role as a modulator of fibroblast growth factor activity. Biochem Soc Trans 21: 477-482, 1993.

VAREDI M, TREDGET EE, GHAHARY A, SCOTT PG: Stress-relaxation and contraction of a collagen matrix induces expression of TGF- $\beta$ and triggers apoptosis in dermal fibroblasts. Biochem Cell Biol 78: 427-436, 2000.

VAUGHAN MB, HOWARD EW, TOMASEK JJ: Transforming growth factor- $\beta 1$ promotes the morphological and functional differentiation of the myofibroblast. Exp Cell Res 257: 180-189, 2000.

WANG Y, TANG Z, XUE R, SINGH GK, LV Y, SHI K, CAI K, DENG L, YANG L: TGF- $\beta 1$ promoted MMP-2

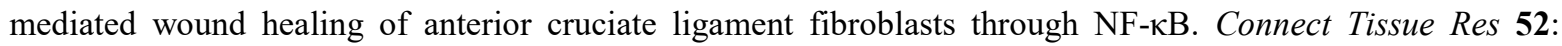
218-225, 2011.

WELLS RG, KRUGLOV E, DRANOFF JA: Autocrine release of TGF- $\beta$ by portal fibroblasts regulates cell growth. FEBS Lett 559: 107-110, 2004.

XIE J, WANG C, HUANG D-Y, ZHANG Y, XU J, KOLESNIKOV SS, SUNG KLP, ZHAO H: TGF-beta1 induces the different expressions of lysyl oxidases and matrix metalloproteinases in anterior cruciate ligament and medial collateral ligament fibroblasts after mechanical injury. J Biomech 45: 890-898, 2013.

YE H, CAI P-C, ZHOU Q, MA W-L: Transforming growth factor- $\beta 1$ suppresses the up-regulation of matrix metalloproteinase-2 by lung fibroblasts in response to tumor necrosis factor- $\alpha$. Wound Repair Regen 19: 392-399, 2011.

YU C, WANG F, JIN C, HUANG X, MILLER DL, BASILICO C, MCKEEHAN WL: Role of fibroblast growth factor type 1 and 2 in carbon tetrachloride-induced hepatic injury and fibrogenesis. Am J Pathol 163: 1653-1662, 2003. 